\title{
COMPARATIVE STUDIES BETWEEN ALUM SYNTHESIZED FROM ALUMINUM CANS AND NATURAL COAGULANT SYNTHESIZED FROM WATERMELON SEED
}

\author{
MUHAMMAD SULAIMAN RAHAMA ${ }^{\mathrm{a} *}$, AHMED LAWAL MASHI ${ }^{\mathrm{a}}$ and \\ ABUBAKAR SANI MUHAMMAD ${ }^{a}$
}

\begin{abstract}
This study focused on the comparative analyses between the alum synthesized from aluminum can and natural coagulant synthesized from watermelon seed in water treatment. It also involved the identification of phytochemical groups of watermelon seed cake. The two different synthesized coagulants were used in jar test analysis; the result obtained showed a good elimination of turbidity and suspended solid particles. The $\mathrm{pH}$ of the natural coagulant of the treated water falls within the range of 6.9 to 7.2. Alkaloid tannins, saponin, anthracene and flavonoid were found present in the watermelon seed cake. Moreover, the result from the research showed that both the natural coagulant synthesized from watermelon seed and the one synthesized from aluminum cans could be used as good flocculant in surface water treatment.
\end{abstract}

Keywords: Watermelon seed cake, Alum, Aluminum can, Coagulation, Phytochemical

\section{INTRODUCTION}

Natural coagulants have been increasingly popular in the past few years due to its benefits and the fact that it resolves most of the associated problems when using chemical coagulants. Plant-based natural coagulants perform coagulation either by polymer bridging or charge neutralization; it can be extracted from various plant components. Coagulation and flocculation processes are widely used in water and wastewater treatment. Its main objective is to remove suspended colloidal particles and to reduce turbidity in water body [1]. The process usually takes place in a chemical reactor in which

\footnotetext{
a Umaru Musa Yaradua University, Faculty of Natural and Applied Sciences, Department of Pure and Industrial Chemistry, Katsina, Nigeria

*Corresponding author: muhammad.sulaimanr@umyu.edu.ng
} 
the influent water or wastewater enter the basin and it is mixed with coagulant agents using a mechanical mixer, followed by sedimentation process to remove the particulate through gravity settling [2]. There are many types of coagulants available. The most often used are the chemical-based coagulants such as alum and ferric salts [3].

A number of studies have pointed out that the introduction of natural coagulants as a substitute for metal salts may ease the problems associated with chemical coagulants. Using natural coagulants instead of aluminium salts might give advantages, such as lower costs of water production, less sludge production and ready availability of reagents. There are also some disadvantages such as increased concentration of nutrients and chemical oxygen demand $(C O D)$ in the treated water due to the organic nature of this type of coagulants [4]. Among plant materials that have been tested over the years, the seeds from Moringa oleifera have been shown to be one of the most effective primary coagulant in water treatment or purification. Moringa oleifera is the best natural coagulant discovered so far that can replace aluminium sulphate (alum), which is used widely for water treatment around the world [5]. Coagulants are formulated to assist in the solids/liquid separation of suspended particles in a solution. Such particles are characteristically very small and the suspended stability of such particles (colloidal complex) is due to both their small size and to the electrical charge between particles [6],[7].

Recently, however, there has been a resurgence of interest in natural coagulants for water treatment in developing countries. For this purpose the greatest degree of attention has been focused on the seed of Moringa oleifera from Sudan, Nirmali seed in India, mesquite bean and in Venezuela, red bean and common bean, sweet corn and so on. These natural coagulants can be used alone or as a substitution for chemical coagulants and flocculants. They can be used for reducing turbidity and microorganisms in water, for water softening and for dewatering sludge [8]. Some of the plants are able to be a coagulant because they are able to conduct some of the coagulation mechanisms which are neutralizing the charge in colloidal particles and perform polymer bridging [9].

Watermelons (Citrullus Lanatus) are a popular seasonal plant in the sub-Sahara and their seeds can be used as effective water purifiers because of their adsorbent properties like most indigenous seeds [10].

Water supply is a basic need required for living creatures and human being specifically. Developing countries and third world countries are facing potable water supply problems because of inadequate financial resources. The cost of water treatment is increasing and the quality of river water is not stable due to suspended and colloidal particle load caused by land development and high storm runoff during the rainy seasons [11]. During the rainy seasons 
the turbidity level increases and the need for water treatment chemicals increase as well, which leads to high cost of treatment which the water treatment companies cannot sustain. As a result, the drinking water that reaches the consumer is not properly treated [5].

Aluminum is one of the most important metals used by modern societies. The combination of the physical properties of aluminium results in its use in a wide variety of products, many of which are indispensable to modern life [12].

In this study, instead of recycling aluminum in to new metal cans, a chemical process will be used to transform the scrap aluminum into a useful chemical compound, potassium aluminum sulfate dodecahydrate, $\mathrm{KAl}\left(\mathrm{SO}_{4}\right)_{2} \cdot 12 \mathrm{H}_{2} \mathrm{O}$, commonly called "alum", then its properties will be compared with a natural coagulant that will be synthesized from watermelon seed; likewise, their effect in water treatment.

\section{RESULTS AND DISCUSSION}

The results of the jar test analysis of the synthesized alum and watermelon seed are highlighted below, likewise phytochemical screening of the watermelon seed and the qualitative analysis of the synthesized alum are shown below.

Table 1. Results of jar test analysis of the synthetic alum

\begin{tabular}{|c|c|c|c|c|}
\hline $\begin{array}{c}\text { Mass of Synthetic Alum } \\
(\mathbf{g})\end{array}$ & $\mathbf{p H}$ & $\begin{array}{c}\text { Turbidity } \\
\text { (NTU) }\end{array}$ & $\begin{array}{c}\text { TDS } \\
(\mathbf{m g} / \mathbf{L})\end{array}$ & $\begin{array}{c}\text { Colour } \\
\text { (Hazen) }\end{array}$ \\
\hline $\mathbf{0 . 5}$ & 6.6 & 5.6 & 44 & 5 \\
\hline $\mathbf{1 . 0}$ & 6.4 & 4.9 & 44 & 5 \\
\hline $\mathbf{1 . 5}$ & 6.2 & 4.3 & 41 & 5 \\
\hline $\mathbf{2 . 0}$ & 5.9 & 3.1 & 38 & 5 \\
\hline $\mathbf{2 . 5}$ & 5.8 & 2.9 & 36 & 5 \\
\hline $\mathbf{3 . 0}$ & 5.3 & 2.3 & 36 & 5 \\
WHO standard & $6.5-8.5$ & 5 max. & 500 & 15 max. \\
\hline Raw water & 7.8 & 734.60 & 325.0 & 73.0 \\
\hline
\end{tabular}

Table 1 above showed the results for jar test analysis using synthetic alum crystals. The values of $\mathrm{pH}$, turbidity, TDS and color were analyzed and recorded. The results indicated that the values of the $\mathrm{pH}$ at varying alum dosage kept increasing to acidic level insignificantly. However, the turbidity also decreases from $5.6 \mathrm{NTU}$ at $0.5 \mathrm{~g}$ to $2.3 \mathrm{NTU}$ at $3.0 \mathrm{~g}$ alum dosages. 
These observations were in accordance with previous studies on coagulation ability of recycled aluminum cans as reported by Birnin-Yauri and Musa [13]. The results for the TDS were also recorded; there is decrease in the TDS values as the concentration of alum dose increases. The secondary standard value for the TDS of drinking water by WHO is $500 \mathrm{mg} / \mathrm{L}$, therefore, the synthetic alum powder has the potential to reduce TDS.

Table 2. Results of jar test analysis of the watermelon seed cake

\begin{tabular}{|c|c|c|c|c|}
\hline $\begin{array}{c}\text { Watermelon seed } \\
\text { cake } \\
\mathbf{( g )}\end{array}$ & $\mathbf{p H}$ & $\begin{array}{c}\text { Turbidity } \\
\text { (NTU) }\end{array}$ & $\begin{array}{c}\text { TDS } \\
\text { (mg/L) }\end{array}$ & $\begin{array}{c}\text { Colour } \\
\text { (Hazen) }\end{array}$ \\
\hline $\mathbf{0 . 5}$ & 6.9 & 28.3 & 83 & 15 \\
\hline $\mathbf{1 . 0}$ & 6.9 & 30.1 & 83 & 15 \\
\hline $\mathbf{1 . 5}$ & 7.0 & 32.6 & 79 & 10 \\
\hline $\mathbf{2 . 0}$ & 7.1 & 33.2 & 76 & 10 \\
\hline $\mathbf{2 . 5}$ & 7.1 & 35.5 & 75 & 5 \\
\hline $\mathbf{3 . 0}$ & 7.2 & 37.2 & 75 & 5 \\
WHO standard & $6.5-8.5$ & $5 \mathrm{max}$ & 500 & 15 max \\
\hline Raw water & 7.8 & 734.60 & 325.0 & 73.0 \\
\hline
\end{tabular}

Table 2 above showed the results for jar test analysis using watermelon seed cake. The values for $\mathrm{pH}$, turbidity, TDS and colour were analysed and recorded. The use of watermelon seed cake as a coagulant to treat water resulted in portable water that met the World Health Organisation (WHO) standards for portable water [14]. The results indicated that the results of $\mathrm{pH}$ showed insignificant decrease as the mass of the watermelon seed cake increases. This was observed at $0.5 \mathrm{~g}$ of the seeds powder where 6.9 were recorded as $\mathrm{pH}$ value and $3.0 \mathrm{~g}$ of the seed powder where 7.2 was recorded as $\mathrm{pH}$ value. This observation was in accordance with previous studies on watermelon seed cake as reported by Muhammad et al., [11]. The values of the turbidity observed indicated that the watermelon seed cake is somehow effective in the removal of turbidity. The greatest decrease was seen at the dose of $0.5 \mathrm{~g} / \mathrm{L}$ of raw water which had a turbidity of $28.3 \mathrm{NTU}$. This value is still above the WHO recommended level of 5 NTU. However, according to Muhammad et al., [11] the optimal dosage for a specific water is defined as the dosage which gives the lowest turbidity in the treated water therefore the optimum dosage is $0.5 \mathrm{~g} / \mathrm{L}$. The results for the TDS were also recorded; there is decrease in the TDS values as the concentration of the watermelon seed cake increases. The secondary standard value for the TDS of drinking water by $\mathrm{WHO}$ is $500 \mathrm{mg} / \mathrm{L}$, therefore, the watermelon seed cake has the potential to reduce TDS. 

NATURAL COAGULANT SYNTHESIZED FROM WATERMELON SEED

Table 3. Results of phytochemical screening of the watermelon seed

\begin{tabular}{|c|c|c|}
\hline S/NO & PHYTOCHEMICALS & COMFIRMATION \\
\hline $\mathbf{1 .}$ & Alkaloid & + \\
\hline $\mathbf{2 .}$ & Tannins & + \\
\hline $\mathbf{3 .}$ & Saponin & + \\
\hline $\mathbf{4 .}$ & Anthracene & + \\
\hline $\mathbf{5 .}$ & Flavonoids & + \\
\hline
\end{tabular}

Key:

+ Presence

- Absence

Table 3 presents the phytochemical analysis of the extracted watermelon seed cake. The extracted seed found to contain the following; component: Alkaloid, Tanins, Saponin, Anthracene and flavonoids.

Table 4. Results of qualitative analysis of the synthesized alum

\begin{tabular}{|c|c|c|}
\hline Test & Observation & Inference \\
\hline $\begin{array}{c}\text { Alum solution }+ \\
\text { Aqueous } \mathrm{BaCl}_{2} \\
\text { Solution }\end{array}$ & $\begin{array}{c}\text { White Precipitate } \\
\text { formed, and insoluble } \\
\text { (After 20 hours) }\end{array}$ & $\begin{array}{c}\mathrm{SO}_{4}{ }^{2-} \\
\text { Confirmed }\end{array}$ \\
\hline $\begin{array}{c}\text { Solid Alum Crystal+ heat } \\
\text { (10 minutes) }\end{array}$ & $\begin{array}{c}\text { Red flame turned to } \\
\text { Pale purple flame color }\end{array}$ & $\begin{array}{c}\mathrm{K}^{+} \\
\text {Confirmed }\end{array}$ \\
\hline $\begin{array}{c}\text { Alum Solution }+\mathrm{H}_{2} \mathrm{SO}_{4}(\mathrm{aq}) \\
\text { in drop and in } \\
\text { Excess }\end{array}$ & $\begin{array}{c}\text { Thick, white gelatinous precipitate } \\
\text { formed insoluble in drop but } \\
\text { soluble in excess }\end{array}$ & $\begin{array}{c}\mathrm{Al}^{3+} \\
\text { Confirmed }\end{array}$ \\
\hline
\end{tabular}

Table 4 presents the qualitative analysis of the synthesized alum crystals, the aluminum, potassium and sulfate ions were positively tested as expected. This is an indication that the synthesized alum crystal possesses all necessary chemical properties expected of any alum crystal. This was also contained in the research made by Birnin-Yauri and Musa [13].

\section{CONCLUSIONS}

From the results obtained in this research, it shows that the use of natural coagulant in water treatment is more effective than the chemical coagulants in terms of $\mathrm{pH}$, because the natural coagulant has a $\mathrm{pH}$ that is neither acidic nor basic, hence neutral which falls within the range of 6.9 to 7.2 , but in terms of turbidity and TDS, the chemical coagulant is more effective than the natural coagulant, it can be concluded that the watermelon seed can be used as natural coagulant for water treatment. 


\section{EXPERIMENTAL SECTION}

\section{Procedure for the synthesis of alum from aluminum can}

The method of Birni-Yauri and Musa [13] was adopted for the synthesis of the alum. Empty aluminum cans were obtained and brought in to the lab, sand paper was used to scrape off paint and plastic coating from both sides as completely as possible. It was then cut at approximately $5 \mathrm{~cm} \times 7.5 \mathrm{~cm}$ by the use of scissor. $1.0 \mathrm{~g}$ of aluminum pieces was weighted and put into $250 \mathrm{~cm}^{3}$ beaker. $50 \mathrm{~cm}^{3}$ of $1.4 \mathrm{M}$ potassium hydroxide was added to the $250 \mathrm{~cm}^{3}$ beaker containing the aluminum pieces. The beaker was then placed on a hotplate, in a fume hood and heated. Bubbles of hydrogen formed from the reaction between aluminum and aqueous potassium hydroxide was observed. The reaction was complete as the hydrogen evolution ceases and there were no visible pieces of aluminum metal. While the reaction was taking place, the initial colorless mixture turns to black. The hot solution was filtered to remove solid residue and black substances in the solution. The clear filtrate solution was transferred into a clean $250 \mathrm{~cm}^{3}$ beaker. As the solution is cooled, $20 \mathrm{~cm}^{3}$ of $9.0 \mathrm{M} \mathrm{H}_{2} \mathrm{SO}_{4}$ was added to the solution and stirred gently, the final solution contained potassium ions (from the $\mathrm{KOH}$ used), aluminum ions, and sulfate ions. The solution was also filtered using filter paper. An ice water bath was prepared and the beaker containing the solution was placed in to the ice water bath and the mixture was allowed to chill. Cold water was added to cover the ice. The reaction beaker was set into the ice-water bath to chill for about 20 minutes. Crystals of the alum began to form in few minutes. The alum crystal formed was filtered from the chilled solution.

\section{Synthesis of coagulant from watermelon seed}

Fresh seed of watermelon were obtained, the seed were washed severally with water and it was allowed to dry for about one week, the dried seed were sorted and the bad ones were removed, it was then ground to powder. $150 \mathrm{~g}$ of the powdered watermelon seed were weighed and placed in a thimble, $500 \mathrm{~cm}^{3}$ of $n$-hexane was added, the thimble was then placed in a soxhlet extractor, it was then allowed to stand for $6 \mathrm{hrs}$, the set up was stopped as the extraction was completed. The powdered seed were washed with distilled water to remove the residual $n$-hexane, the residue was then dried in an oven till constant weight was obtained. The finer particle finally obtained was termed as coagulant [11]. 


\section{Procedure of Jar Test Analysis}

The procedure of Katsina State Water Board manual for water treatment and analyses, 2019 was used. The jar test machine was switched on and set at low speed. The raw water sample was put in 6 different beakers of 1000 $\mathrm{cm}^{3}$, where different grams of $0.5 \mathrm{~g}, 1 \mathrm{~g}, 1.5 \mathrm{~g}, 2 \mathrm{~g}, 2.5 \mathrm{~g}$ and $3 \mathrm{~g}$ were used for the synthesized alum. The raw water sample was then added to make up the $1000 \mathrm{~cm}^{3}$ mark and the jars were then placed in the jar test kit and the stirrers lowered into each. The speed of the jar test machine was then set at 400rpm for 10 minutes; which was later set at low speed again. This is to allow the merging of the smaller flocs formed to larger one. The procedure was repeated for watermelon seed cake.

\section{Determination of $\mathrm{pH}$}

The 2 water samples $\left(100 \mathrm{~cm}^{3}\right.$ each) were transferred into a clean dried glass beaker, then the electrodes of standardized $\mathrm{pH}$ meter was immersed and the meter was allowed to standardized, after which the reading was taken. The electrode was rinsed well with distilled water and tabbed slightly with tissue paper after each test as described by Geotechnical Engineering Bureau, 2007.

\section{Determination of Turbidity}

The 2 samples of the water were transferred into the sample cell turbidity meter up to the horizontal mark, then wiped with tissue paper and subsequently placed in the turbidity meter such that the vertical mark in the sample cell coincide with the mark in the turbidity meter, after which it was covered. The readings displayed on the screen and were recorded, as described by Manual of Water Treatment and Analysis, Katsina State Water Board, 2009.

\section{Determination of TDS}

The TDS of the samples were analyzed using TDS meter. The samples were put in a clean beakers and the head of the TDS meter was immersed in the beakers. Readings were taken for each sample separately, as described by Manual of Water Treatment and Analysis, Katsina State Water Board 2009.

\section{Determination of Color}

The color of the 2 water samples was analyzed using comparator and Disc, where the samples were put in different tubes of $10 \mathrm{~cm}^{3}$, and then inserted in the hole of the comparator. The disc was then scroll until a suitable 
and matching color was observed for each sample. The reading of the corresponding color for each was recorded, as described by Manual of Water Treatment and Analysis, Katsina State Water Board 2009.

\section{Procedure for the phytochemical analysis}

Alkaloid: $1 \mathrm{~cm}^{3}$ of the extract was stirred with $5 \mathrm{~cm}^{3}$ of $10 \%$ aqueous hydrochloric acid on a steam bath for 20 minutes, cooled and filtered. $1 \mathrm{~cm}^{3}$ of the filtrate was treated with few drops of Mayer's reagent. A creamy precipitate was observed which indicated the presence of alkaloids [15].

Tannins: $3 \mathrm{~cm}^{3}$ of the diluted extract was pipetted into a clean test tube; ferric acid chloride solution was added dropwise into the extract. Blue black colouration was observed which indicated the presence of tannin [16].

Saponins: $5 \mathrm{~cm}^{3}$ of the diluted extract was pipetted into a clean test tube and corked with cotton wool and shaken for about 3 minutes. Persistent froth was o0bserved which indicated the presence of saponin [16].

Anthracene: $4 \mathrm{~cm}^{3}$ of the diluted extract was pipetted into a clean test tube; equal volume of chloroform was added and shaken. The mixture was allowed to separate into two layers. The chloroform layer was collected and $1 \mathrm{~cm}^{3}$ of $10 \%$ ammonia solution was added and shaken, a brick red precipitate was observed which indicated the presence of anthracene [16].

Flavonoids: $3 \mathrm{~cm}^{3}$ of the exract was placed in a test tube, $3 \mathrm{~cm}^{3}$ of $0.1 \mathrm{M} \mathrm{HCl}$ was added, $0.5 \mathrm{~cm}^{3}$ of $0.5 \mathrm{M} \mathrm{NaCl}$ was added. A yellow colour was observed which indicated the presence of flavonoids [16],[17].

\section{ACKNOWLEDGMENTS}

We wish to acknowledge the effort of the department of pure and industrial chemistry, Umaru musa Yaradua University Katsina, Katsina State, Nigeria.

\section{REFERENCES}

1. S.Y. Choy; K.M.N. Prasad; T.Y. Wu; M.E Raghunandan; R.N. Ramanan; Journal of Env. Sci., 2014, 26, 2178-2189.

2. M.J. Hammer; Jr. M.J. Hammer; Int. J. App. Env. Sci., 2004, 3, 469-487.

3. I.N. Fathinatu; R. Nithyanandam; Int. J. Eng. \&Tech., 2014, 7, 34-37.

4. Y.S. Daniyan; A.M. Enemaduku; E.O. Eru; Int. J. Res. in Ayurveda \& pharm., 2011, 2, 1265-1270. 
COMPARATIVE STUDIES BETWEEN ALUM SYNTHESIZED FROM ALUMINUM CANS AND NATURAL COAGULANT SYNTHESIZED FROM WATERMELON SEED

5. S.A. Muyibi; E.N. Ali; H.M. Salleh; Thirteenth Int. Water Tech. Conf., 2009, 13, 1-10.

6. C. Deepika; S. Dipak; P. Anjani; Eur. Chem. Bull., 2013, 2, 880-886.

7. E.S. Salem; J. Bakir; M.E. Ahmed; A.E. Ahmed; Int. J. Eng. App. Sci., 2014, 1, 19-24.

8. A.G. Mirjana; S. Marina; P. Nada; Bioresource tech., 2010, 10, 2167-2172.

9. H. Kristiano; J. of Water Cons. of Sci. and Eng., 2017, 2, 51-60.

10. S. Malunjkar; K.R. Ambekar; Int. J. of Eng. and Tech. Res., 2015, 3, 263-266.

11. I.M. Muhammad; S. Abdulsalam; A. Abdulkarim; A.A. Bello; Global J. of Res. in Eng.: Chem. Eng., 2015, 15, 17-24.

12. A.L. Adejumo; R.U. Owolabi; S.A. Adebisi; W.A. Agbaje; M.A. Usman; J. Eng. App. Sci., 2016, 3, 8-13.

13. A.U Birnin-Yauri; A. Musa; Int. J. of Adv. Res. in Chem. Sci., (IJARCS) 2014, 1, 1-6.

14. M.M. Musaida; C. Tawanda; Int. Conf. on P. and App. Chem., ICPAC: Emerging Trends in Chemical Sciences. 2016, 1, 1-6.

15. E.A. Sofowora; Medical plants and Traditional plants in Africa; John Willey and Sons, New York; 1982, Pp 1-20.

16. M.M. El-olemy; F.J. Al-muhtadi; A.A. Afifi; Experimental phytochemistry: A laboratory manual, King Fahad University Press; Saudi Arabia, 1994, pp. 3-19.

17. J.B. Harbone, Examination of Flavonoid Aglycones in Hydrolysed Plant Extracts, in Phytochemical methods, Chapman and Hall, London: 1973, pp. 1-32. 